\title{
Evaluation of two production methods of Chilean wheat by life cycle assessment (LCA)
}

\author{
Evaluación de dos estilos productivos de trigo chileno mediante metodología \\ de análisis de ciclo de vida (ACV)
}

\author{
Joaquín Herrera Huerta $^{1 *}$, Edmundo Muñoz Alvear ${ }^{2}$, René Montalba Navarro ${ }^{3}$
}

\begin{abstract}
Agricultural production is an activity that generates environmental impacts, primarily associated with the use of machinery and chemical inputs. For this reason it is expected that cultural practices and technological levels will influence significantly the environmental impacts of different production systems. In this study we evaluated conventional and organic methods using life cycle assessment (LCA). The results identified soil management as the stage of conventional production that generates the greatest environmental impact; the most affected impact categories were acidification, with $15.28 \mathrm{~kg} \mathrm{SO}_{2}$ equivalent per ton of grain produced, and eutrophication, with $4.83 \mathrm{~kg} \mathrm{PO}_{4}$ eq/ton of grain. The category most affected by organic production was soil management, mainly due to the Diesel fuel used in agricultural machinery. In this production method the category of abiotic resource depletion had the greatest impact, with $0.89 \mathrm{~kg} \mathrm{Sb}$ eq/ton of grain. The use of compost as a strategy fixed important amounts of biogenic carbon, generating environmental benefits in the impact category of climate change $-4.39 \mathrm{~kg} \mathrm{CO}_{2}$ eq/ton of grain.
\end{abstract}

Key words: conventional production, organic production, environmental impact.

\section{RESUMEN}

La producción agrícola es considerada una actividad generadora de impactos ambientales, los que se asocian principalmente al uso de maquinaria e insumos agroquímicos. Por este motivo, se prevé que las prácticas culturales y el nivel de tecnificación influyen significativamente sobre los impactos ambientales de los distintos sistemas productivos. En este trabajo se evaluaron los estilos convencional y orgánico mediante la metodología de análisis de ciclo de vida (ACV). Los resultados identificaron el manejo de suelo como la etapa de la producción convencional que genera mayor impacto ambiental, siendo las categorías de impacto acidificación con $15,28 \mathrm{~kg} \mathrm{SO}{ }_{2}$ equivalente por tonelada de grano producido y eutrofización con $4,83 \mathrm{~kg} \mathrm{PO}_{4}$ eq/ton de grano las mas afectadas. Para el estilo productivo orgánico las cargas de mayor importancia se registraron en el manejo de suelo, debido principalmente al diésel utilizado en la maquinaria agrícola. En este estilo productivo la categoría de agotamiento de recursos abióticos presentó el mayor impacto, con 0,89 kg Sb eq/ton de grano, siendo el uso de compost una estrategia debido a que éste fija cantidades importantes de carbono biogénico generándose beneficios ambientales en la categoría de impacto de cambio climático con $-4,39 \mathrm{~kg} \mathrm{CO}$ eq/ton de grano.

Palabras claves: producción convencional, producción orgánica, impacto ambiental.

\section{Introduction}

Traditional agricultural production methods have profound effects on the environment. They are the main source of the contamination of water, air and soil, reducing biodiversity and agricultural genetic diversity (FAO, 2007). Wheat production in Chile is dominated by the model originated by the green revolution called conventional production. This method produces high yields, with an ideal quality for baking bread. To achieve this, improved seed varieties which are compatible with the available technology must be used, in order to exploit the full potential of a wheat variety (Mellado, 2007).

\footnotetext{
1 Programa Magíster en Ciencias Agropecuarias, Facultad de Ciencias Agropecuarias y Forestales. Universidad de La Frontera. Av. Francisco Salazar 01145. Temuco, Chile.

2 Instituto del Medio Ambiente. Universidad de La Frontera. Av. Francisco Salazar 01145. Temuco, Chile.

3 Departamento de Ciencias Agronómicas y Recursos Naturales. Universidad de La Frontera. Av. Francisco Salazar 01145. Temuco, Chile.

* Autor, e-mail: jahh.agroeco@gmail.com
}

Fecha de Recepción: 19 Marzo, 2012.

Fecha de Aceptación: 10 Junio, 2012. 
However, this system requires the farmer to use highly mechanized technological procedures for pure cultures, with elevated requirements of fertilizer and pesticides (Montalba, 2009).

Currently, farmers, consumers, government institutions and researchers are interested in a more sustainable agriculture which incorporates technologies that are cleaner and friendlier to human and environmental health. This type of agriculture appears as an alternative which intends to develop highly efficient production formulas that take advantage of the natural and cultural potentialities of an area, without destroying the soil, water, air, organisms or the surrounding area (Céspedes, 2005). Comparing different agricultural methods allows the identification of their consequences in terms of the pressures they exert on the environment (Schmitzberger et al., 2005), since each is related to the way the producer operates, the markets, natural resources and specific technologies (Gastó et al., 2002).

One way to evaluate production methods in environmental terms is by using the methodology of Life Cycle Assessment (LCA), This method has been used in studies of vegetables (Antón, 2004), fruit trees (Pizzigallo et al., 2008), rice (Blengini and Busto 2009), wheat (Meisterling et al., 2009), grasslands (Haas et al., 2001), milk (Hospido et al., 2003), soil use (Peters et al., 2003), as well as local factors of agricultural production (Milá, 2003), which shows its usefulness in analyses of the potential environmental impact of agricultural production during a life cycle.

The objective of this study is to evaluate and compare in environmental terms two production methods for wheat, conventional and organic, using the methodology of LCA.

\section{Materials and Methods}

The study was performed in the 2008-2009 season in the Campo Experimental Maquehue that belongs to the Universidad de La Frontera, located at $38^{\circ} 50^{\prime} 38.33^{\prime \prime} \mathrm{S}$ and $72^{\circ} 41^{\prime} 57.65^{\prime \prime} \mathrm{W}$ at an altitude of $80 \mathrm{~m}$ in the intermediate depression of the central valley, in the Comuna de Padre Las Casas, Sector Maquehue-Chile. It is located in the agroecological area of La Araucanía called central valley, characterized by a cold temperate climate with 115 days without freezes in the summer period; freezes begin to occur in March. The sum of day-degrees is $900{ }^{\circ} \mathrm{C}$ (base $5^{\circ} \mathrm{C}$ ); the annual precipitation is 1350 $\mathrm{mm}$; the dry season lasts 3.5 months and the humid season begins in April (Rouanet et al., 1988). The soil is light textured of the Freire series, an Andisol derived from recent volcanic ash, with slopes of 0-2\% (INIA, 1985).

Two production systems were evaluated in this study, (i) conventional production and (ii) organic production, whose details are given in Table 1.

Table 1. Determinants of the agro-ecosystem for the conventional and organic production of wheat evaluated in the study.

\begin{tabular}{|c|c|c|c|}
\hline \multicolumn{2}{|c|}{ Determinants of the Agro-Ecosystem } & Conventional System & Organic System \\
\hline \multicolumn{2}{|c|}{ Species and varieties managed } & Trigo var. Dollinco & Trigo Ecotype Linaza ${ }^{a}$ \\
\hline \multicolumn{2}{|l|}{ Sowing } & Fine grain seeder & Fertilizer spreader \\
\hline \multirow{3}{*}{ Soil management } & Preparation & $\begin{array}{c}\text { Stubble burning } \\
\text { Plowing } \\
\text { Harrowing } \\
\text { Seedbedding } \\
\end{array}$ & $\begin{array}{l}\text { Plowing } \\
\text { Harrowing }\end{array}$ \\
\hline & Fertilization & Tractor with fertilizer spreader & $\begin{array}{c}\text { Tractor towing carriage for } \\
\text { compost application }\end{array}$ \\
\hline & Conservation & n.a. ${ }^{b}$ & $\begin{array}{c}\text { Elaboration of compost using } \\
\text { stubble of the crop }\end{array}$ \\
\hline \multirow{3}{*}{ Sanitary management } & Diseases & Fungicide spraying & n.a. \\
\hline & Weeds & $\begin{array}{l}\text { Spraying of chemical fallow, } \\
\text { total herbicide and Graminicide }\end{array}$ & n.a. \\
\hline & Pests & n.a. & n.a. \\
\hline Harvest & & $\begin{array}{c}\text { Harvester } \\
\text { Tractor }+ \text { towing carriage }\end{array}$ & $\begin{array}{c}\text { Harvester } \\
\text { Tractor }+ \text { towing carriage }\end{array}$ \\
\hline
\end{tabular}

\footnotetext{
${ }^{\text {a }}$ Contreras, 2006 y 2007; b n.a. $=$ Not applicable.
} 


\section{Objective and scope of the life cycle analysis (LCA)}

The objective of the study was to evaluate the environmental effect of two wheat production systems in the Región de La Araucanía using the LCA methodology, identifying the critical points in the production life cycle. The productive study considered the processes utilized in the fields, excluding post-harvest management, that is, a LCA from the cradle to the gate of the field. We also included the processes of extraction of raw material and the production of inputs.

\section{Functional unit (UF) and the system boundary}

The function of the system consists in producing a quantity of wheat grains harvested in one season, thus the functional unit selected was 1 ton of wheat. The scope of this study will be from "the cradle to the gate of the field" (Figure 1), which means that the system only considered management within the farm. We included foreground systems, which are the direct agricultural entrances that are a function of the management associated with production, these managements being agronomical production practices which play a role in the system, and background processes, which are indirect agricultural inputs that are a function of management associated with production, such as the processes of extraction and production both of inputs and machines which fulfill their function outside of the foreground system; because these are the same for both productive systems they are considered in the study.

\section{Data quality and positive environmental impacts}

The data used to calculate potential emissions were obtained in the field, and included from preparation of the soil to harvest. The information was provided by the administrator of the farm, and was combined with information published by Gonzáles et al. (2000). The data include the extraction and production of inputs and fuel, which were obtained from the Ecoinvent data base (Hischier et al., 2009) using the software SimaPro 7.3. The LCA is a balance of inputs and outputs, because of which the use of compost, that allows the capture of carbon in the soil (EPA, 2010), is considered an environmental benefit or positive impact.

\section{Inventory analysis and destination of field emissions}

The data were obtained from information recorded in the field, literature, data bases, specialists and administrators. The inventory of agricultural inputs per functional unit and yield with conventional and organic management is shown in Table 2. The calculation of emissions evaluated particularly nitrogenous fertilizers such as urea (Brentrup et al., 2000 e IPCC, 2006), phosporous and potassium fertilers and pesticides, by means of the Ecoinvent

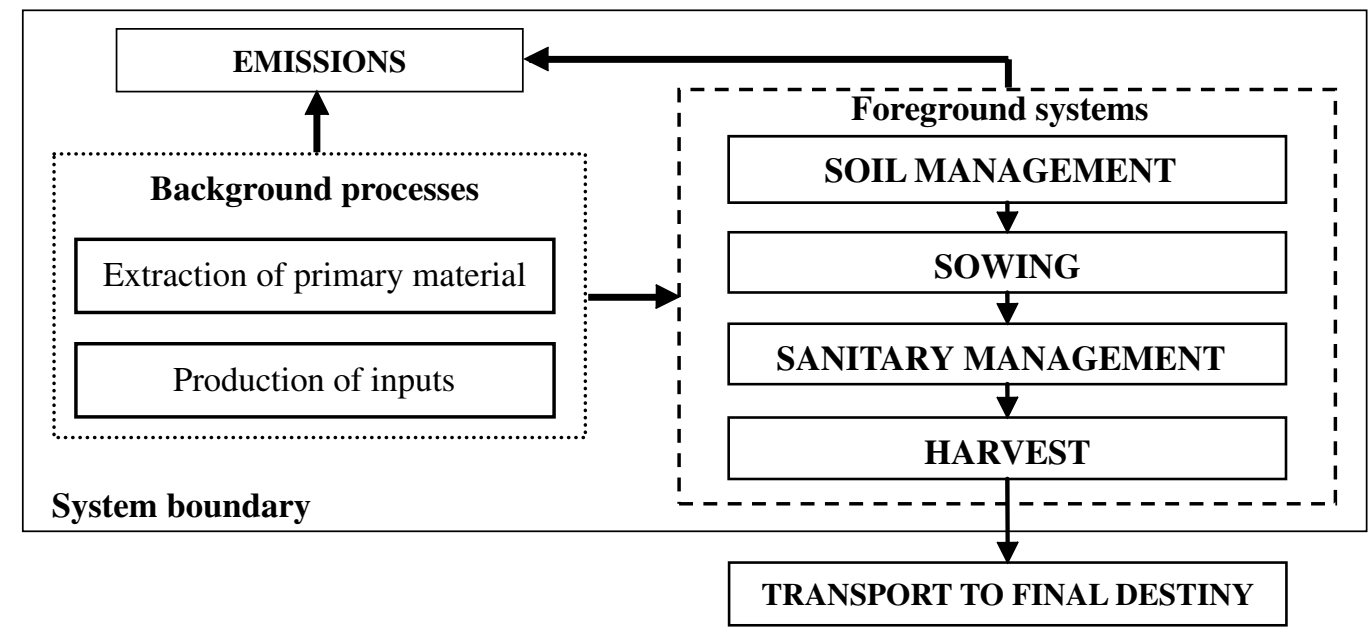

Figure 1. Limits of the wheat production system under study. 
Table 2. Inventory of agricultural inputs (by functional unit) and yield of conventional and organic crops of wheat.

\begin{tabular}{|c|c|c|c|}
\hline Agricultural input & Unit & Conventional wheat & Organic wheat \\
\hline \multicolumn{4}{|l|}{ Seeds } \\
\hline Seeds for sowing & $\mathrm{kg}$ & 35.3 & 44.0 \\
\hline \multicolumn{4}{|l|}{ Fertilizers } \\
\hline Urea & $\mathrm{kg}$ & 45.3 & n.a. ${ }^{1}$ \\
\hline Phosphorous & $\mathrm{kg} \mathrm{P}_{2} \mathrm{O}_{5}$ & 35.6 & n.a. \\
\hline Potassium & $\mathrm{kg} \mathrm{K}_{2} \mathrm{O}$ & 13.5 & n.a. \\
\hline Compost & $\mathrm{Kg}$ & n.a. & $2,829.5$ \\
\hline \multicolumn{4}{|l|}{ Pesticides } \\
\hline Chemical fallow & kg i.a. ${ }^{2}$ & 3.5 & n.a. \\
\hline Funguicide & kg i.a. & 13.6 & n.a. \\
\hline Graminicide & kg i.a. & 0.1 & n.a. \\
\hline Total herbicide & kg i.a. & 0.2 & n.a. \\
\hline \multicolumn{4}{|l|}{ Diesel consumption } \\
\hline Chemical fallow & $\mathrm{kg}$ & 1.9 & n.a. \\
\hline Plowing & $\mathrm{kg}$ & 13.6 & n.a. \\
\hline Harrowing & $\mathrm{kg}$ & 4.7 & 13.3 \\
\hline Seedbedding & $\mathrm{kg}$ & 3.5 & 5.0 \\
\hline Sowing & $\mathrm{kg}$ & 3.8 & 3.7 \\
\hline Herbicide application & $\mathrm{kg}$ & 7.0 & n.a. \\
\hline Fertilizer application & $\mathrm{kg}$ & 7.6 & 10.0 \\
\hline Harvest & $\mathrm{kg}$ & 2.8 & 4.0 \\
\hline Total Diesel consumption & $\mathrm{kg}$ & 46.4 & 36.0 \\
\hline Yield & $\mathrm{kg} / \mathrm{ha}$ & 4,528 & 1,988 \\
\hline
\end{tabular}

${ }^{1}$ n.a. $=$ Not applicable ${ }^{2} \mathrm{~kg}$ i.a. $=$ Kilogram of active ingredient.

data base. The emissions due to the use of fuels and stubble burning were estimated using the directories of the IPCC (2006). The emissions due to the use of compost were obtained from published articles of the EPA (2010) and IPCC (2006).

\section{Evaluation of impact}

The purpose of this phase is to evaluate the significance of the potential impacts using the results of the inventory, associating them with specific categories of environmental impact and with the indicators of these categories (ISO 14044, 2006). The study included the obligatory stages of selection, classification and characterization of impacts, and only the normalization of the optional stages.

\section{Methodology of impact evaluation of the life cycle}

The methodology employed was the CML 2000 (Institute of Environmental Sciences of the
University of Leiden, Holanda), which defines an environmental profile by quantifying the environmental effect of various categories of the product, process or service analyzed (Muñoz, 2008). The methodological guide of the CML 2000 (Guinée et al., 2002) provides a list of impact categories classified as obligatory, additional and others. A unit of reference is established for each of the categories, expressing the impact as the equivalent quantity of each of the components as a function of the characterization factors. The data obtained were analyzed using the software SimaPro 7.3, which allows LCA to be performed using its own inventory data and bibliographic information.

\section{Results and Discussion}

\section{Evaluation of the impact of conventional versus organic wheat production}

According to Roy et al. (2009), the critical life stage in food production is agricultural production. This is shown in the studies cited by De Gennaro 
Table 3. Environmental impact values resulting from the category characterization step using the CML 2000 methodology.

\begin{tabular}{llcr}
\hline Impact category & Unit & Conventional & Organic \\
\hline Depletion of abiotic resources & $\mathrm{kg} \mathrm{Sb} \mathrm{eq}$ & 3.01 & 0.89 \\
Acidification & $\mathrm{kg} \mathrm{SO}_{2}$ eq & 15.28 & 1.01 \\
Eutrophication & $\mathrm{kg} \mathrm{PO}_{4} \mathrm{eq}$ & 4.83 & 0.22 \\
Global warming & $\mathrm{kg} \mathrm{CO}_{2} \mathrm{eq}$ & 792.76 & -4.39 \\
\hline
\end{tabular}

et al., (2011), which include examples such as the production of bread (Braschkat et al., 2003), pasta (Bevilacqua et al., 2007), cheese (Berlin, 2002) and many others. It is also important to consider the local factors in the analysis of agricultural products (Milà, 2003), taking into account the conditions of climate and soil of the production area. Table 3 shows the values of the categories of environmental impact for the wheat production systems analyzed. Conventional production produced greater environmental impact in all the categories evaluated, which identifies organic production as the more environmentally friendly option, even when the data were normalized with world values to appreciate the relative importance of each impact category (Figure 2). Environmental impacts were generated by the items associated with the management utilized; the system of conventional production had a greater potential to impact the environment (Haas et al., 2001; Milà, 2003; Pizzigallo et al., 2008; Blengini and Busto, 2009; Meisterling et al., 2009; Nemecek et al., 2011).

Milà (2003) indicated that organic production is not necessarily more ecological, since although it reduces one impact by not using pesticides, it produces more environmental damage due to the greater use of machinery. Blengini and Bustos (2009) reported that although organic production reduced the environmental impact within its production, the grain yields were low, reducing the environmental benefits per kilogram of final product. In contrast, Hokazono and Hayashy (2012) showed that if the conventional-organic transition is evaluated, in the selected impact categories organic production produced more environmental impact compared to conventional production, due mainly to the instability of production in the initial years.

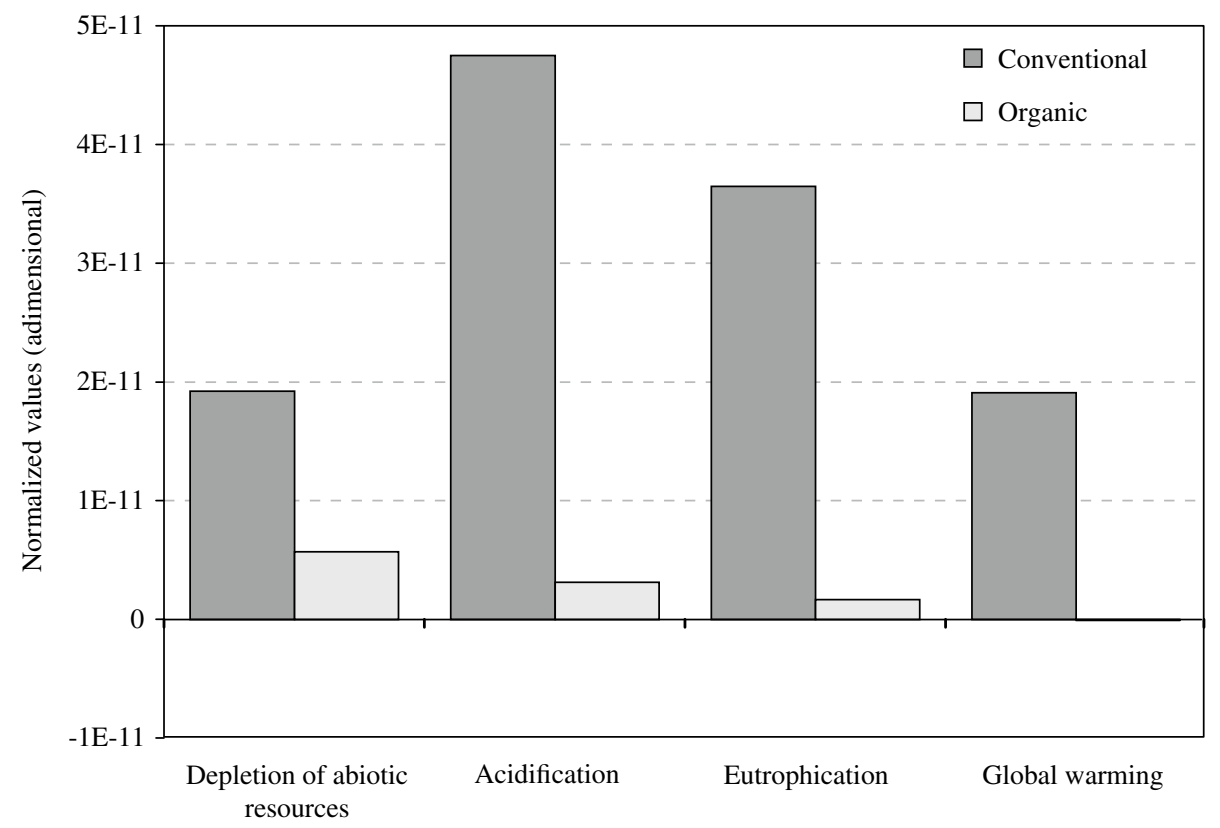

Figure 2. Normalized results of conventional and organic production of wheat using the CML 2000 methodology. 


\section{Evaluation of the impact of conventional production}

This production system uses a high level of extra-farm inputs, which are potential sources of environmental impact since they are associated principally with extraction, production and use. Figure 3 shows that the conventional production method had environmental impact in all the impact categories; soil management was the factor most responsible, since it involves greater use of inputs and machinery. The normalization of the data revealed the importance of these results; eutrophication and acidification were the categories with greatest impact. Figure 4 details the stages and substances which produced the greatest contribution to environmental impact on acidification; the main contributors were the use of urea, with $12.2 \mathrm{~kg} \mathrm{SO}$ eq/ton of grain and the emissions of ammonia, with $12.5 \mathrm{~kg} \mathrm{SO}$ eq/ton of grain. This is explained by the losses associated with the application of urea to the soil, $15 \%$ of the total urea applied was lost by lixiviation. The total impact associated with acidification reached $15.3 \mathrm{~kg}$ $\mathrm{SO}_{2}$ eq/ton of grain. This is produced by the use of synthetic nitrogenous fertilizers and varies according to the dose applied (Brentrup et al., 2004b) and the type of fertilizer employed (Charles et al., 2006).
Although there are no previous studies of LCA for wheat in Chile, Iriarte et al. (2010) studied the production of sunflowers and raps as energy crops for Chile, finding a high contribution due to the use of nitrogenous fertilizer; the greatest impacts were found in the acidification and eutrophication indicators, following the management pattern based on the use of inorganic fertilizers.

Fertilization in conventional production is based on urea, whose use may produce important emissions due to the volatilization of $\mathrm{NH}_{3}$ during and after application, as well as emissions of $\mathrm{SO}_{2}$ and $\mathrm{NO}_{\mathrm{x}}$ (Brentrup et al., 2000). This is corroborated with our results, in which the $\mathrm{NH}_{3}$ emissions attributed to the acidification potential contributed the greater part of the emissions of $\mathrm{SO}_{2}$. As the dosage of inorganic fertilizer increases, so does the acidification potential, producing greater environmental impact (Brentrup et al., 2004b). The use of nitrogen fertilizer in conventional production is also the main cause of eutrophication; the greatest emissions are the lixiviates of $\mathrm{NO}_{3}$, and $\mathrm{NO}_{\mathrm{x}}$ and $\mathrm{NH}_{3}$, which eventually are deposited in surface water (Brentrup et al., 2004b). Figure 5 illustrates the stages and substances which contributed most to the eutrophication category of environmental impacts. The use of urea and the emissions of ammonia

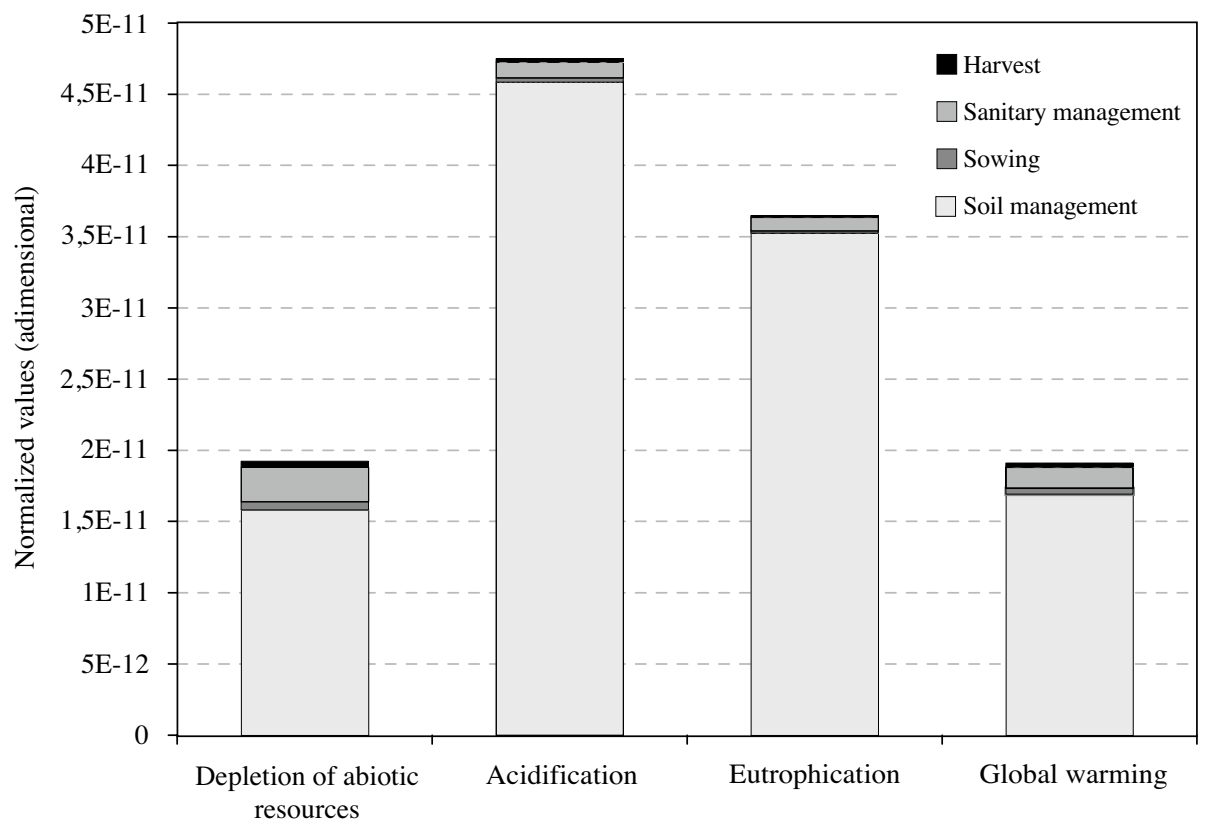

Figure 3. Normalized results of the conventional production of wheat and its contribution to environmental impact categories. 

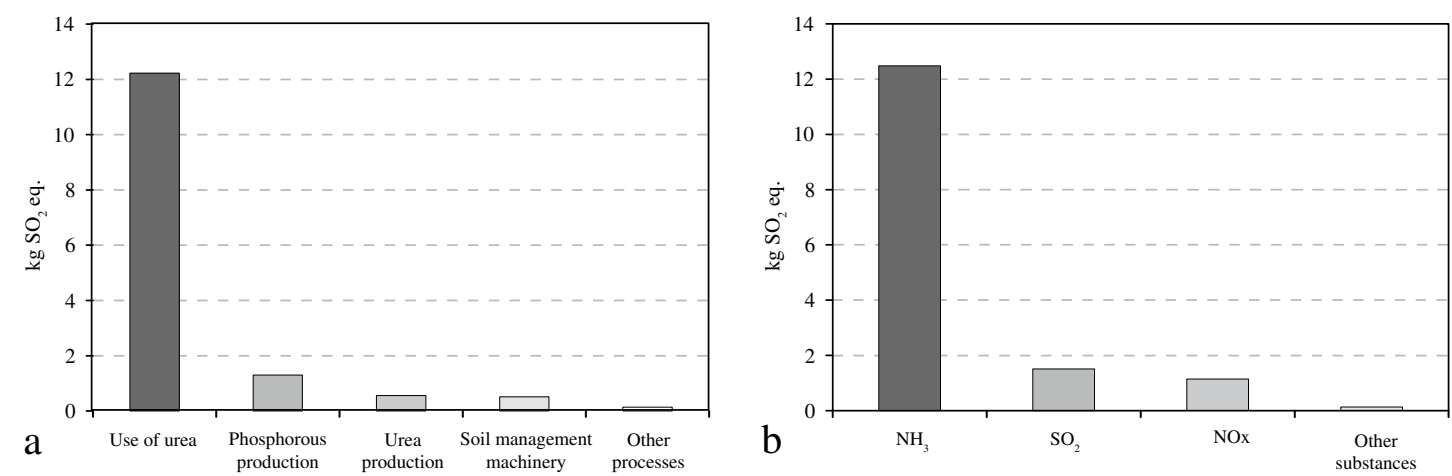

Figure 4. Contribution of environmental impacts produced by conventional production on the acidification impact category, for process step (a) and substances (b).
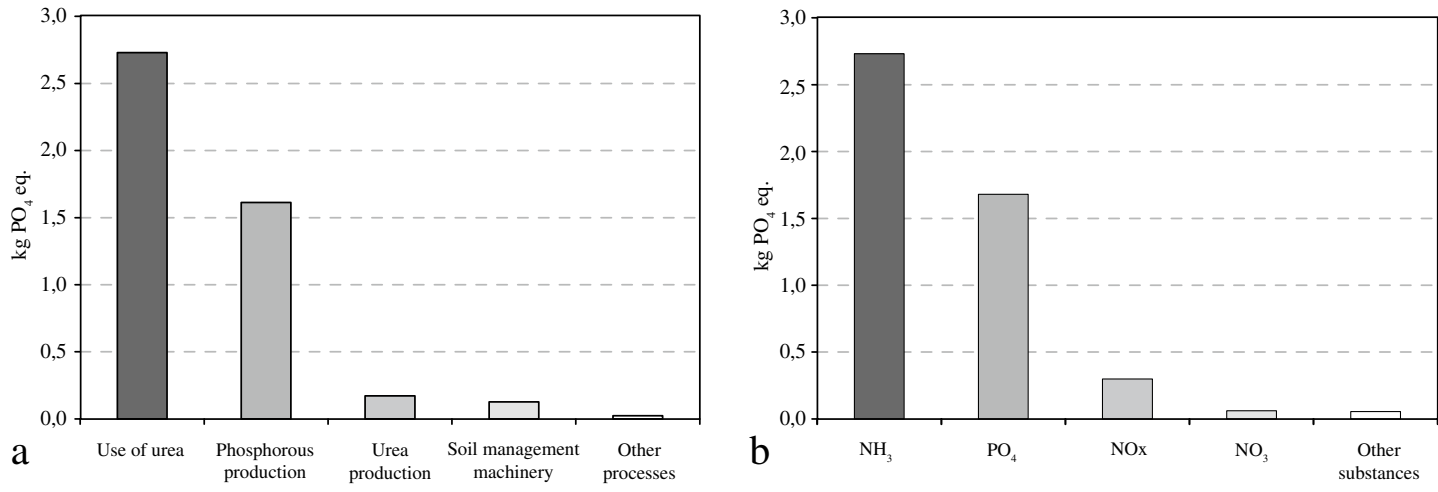

Figura 5. Contribution of environmental impacts produced by conventional production on impact category eutrophication, by process step (a) and substances (b).

associated with its application, which produced $2.7 \mathrm{~kg} \mathrm{PO}_{4} \mathrm{eq} /$ ton of grain, were the main factors responsible for the effect on this category. The total impact associated with eutrophication reached 4.8 $\mathrm{kg} \mathrm{PO}_{4}$ eq/ton of grain. The use of phosphorous in agricultural production contributes to the eutrophication of fresh water due to its stimulation of the growth of noxious algae such as Cyanobacterias and Pfiesteria, which with high phosphorous levels, produced by superficial runoff loss or subterranean flow of applications in excess of the needs of the crops, decrease the oxygen in the water and eventually increase the growth of these anaerobic species (Sharpley et al., 2001).

\section{Evaluation of the impact of organic production}

The results for organic production (Figure 6) show that the greatest environmental impacts were produced in the soil management process; the category of depletion of abiotic resources had the greatest impact, mainly due to the consumption of diesel fuel during the agricultural processes, which reached $0.89 \mathrm{~kg} \mathrm{Sb}$ eq/ton of grain. Figure 7 shows the stages and substances responsible for the environmental impacts in the category of global warming. The machines used in soil management had the greatest impact, with $106 \mathrm{~kg} \mathrm{CO}_{2}$ eq/ton of grain, associated mainly with soil preparation and fertilization; the other main gasses emitted were $\mathrm{N}_{2} \mathrm{O}$, with $265.8 \mathrm{~kg} \mathrm{CO}$ eq/ton of grain, and $\mathrm{CH}_{4}$ with $264.1 \mathrm{~kg} \mathrm{CO}_{2}$ eq/ton of grain. As compost undergoes the process of stabilization of the organic material it generates biogenic emissions of $\mathrm{CO}_{2}$, which were not included. The use of compost contributed $-660.3 \mathrm{~kg} \mathrm{CO}_{2} \mathrm{eq} / \mathrm{ton}$ of grain to the category of global warming due to the carbon fixed. After subtracting the emissions produced by the other processes involved, the final $\mathrm{CO}_{2}$ was -168 $\mathrm{kg} \mathrm{CO}$ eq/ton of grain. 


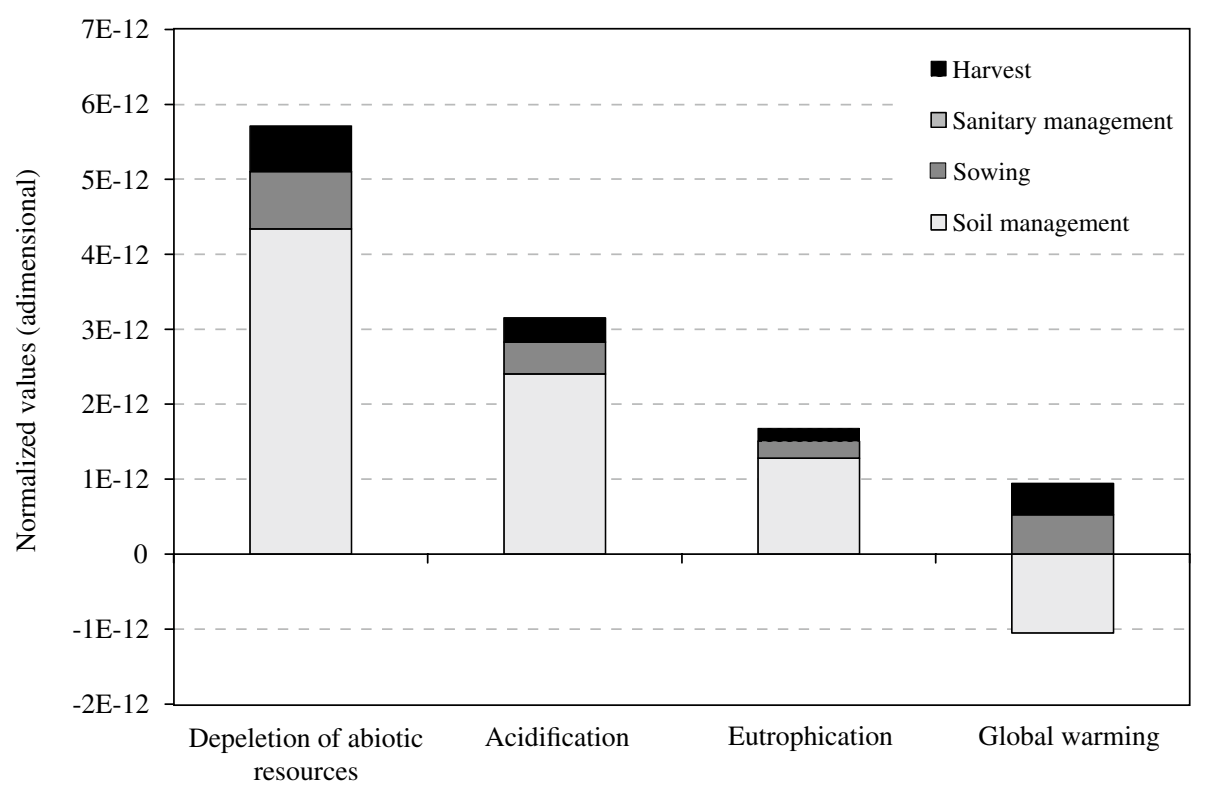

Figure 6. Normalized results of organic production of wheat and their contribution to the impact categories.
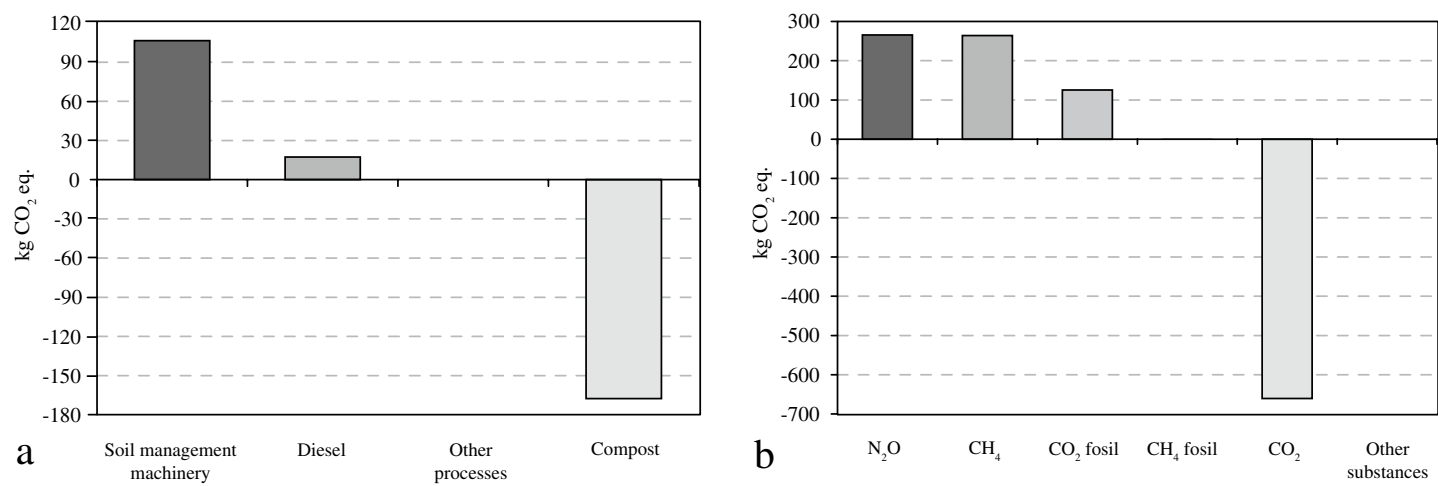

Figure 7. Contributions of environmental impacts produced by organic production on the impact category global warming, by process step (a) and substances (b).

The fertilizers used in organic production have low environmental impact, and in some cases such as compost they have positive environmental impact. Compost production involves an aerobic process in which $\mathrm{CO}_{2}$, water and a fraction of the humic acids interact to obtain stabilized organic matter from plant remains (Bogner et al., 2007). Stabilized organic matter does not produce $\mathrm{CO}_{2}$ emission, since its emissions are of biogenic origin (produced naturally), because of which they are not considered in the final balance (IPCC, 2006; EPA, 2010). Also, EPA (2010) indicated that applying compost contributes to the environment, since the $\mathrm{CO}_{2}$ which could potentially be emitted to the atmosphere is being fixed in the stable organic matter. The results of organic wheat production coincided with the above, and consider compost as a fundamental part of soil management. Although most research on this soil additive have concentrated on improving production and final quality, more attention should be paid to the contribution of the elaboration processes to greenhouse effect gasses (Lou and Nair, 2009).

\section{Conclusions}

The potential environmental impacts of the studied productive systems were clearly differentiated as 
a function of the type of management; conventional production produced greater impacts in the categories of acidification, depletion of abiotic resources, climatic change and eutrophication.

Soil management was the stage which generated the greatest environmental impacts, in both production systems.

Urea was the input which produced the greatest impact in conventional production; the categories of acidification and eutrophication were the most affected by its application.

The principal environmental impacts of organic production were associated with the use of machinery, which affected mainly the categories of depletion of abiotic resources and climate change. In spite of this, the use of compost allowed a decrease in the final impact on climate change, since compost fixes carbon in the soil, producing a positive environmental impact.

\section{Literature Cited}

Antón, A.; Castells, F.; Montero, J.I.; Huijbregts, M. 2004 Comparison of toxicological impacts of integrated and Chemicals pest Management in Mediterranean greenhouses. Chemosphere 54: 1225-1235.

Berlin, J.

2002 Environmental life cycle assessment (LCA) of Swedish semi-hard cheese. International Dairy Journal 12: 939-953.

Bevilacqua, M.; Braglia, M.; Carmignani, G.; Zammori, F.A., 2007 Life cycle assessment of pasta production in Italy. Journal of Food Quality 30 (6): 932-952.

Blengini, G.; Busto, M.

2009 The life cycle of rice: LCA of alternative agri-food chain management systems in Vercelli (Italy). Journal of Environmental Management 90: 1512-1522.

Bogner, J.; Ahmed, M.A.; Diaz, C.; Faaij, A.; Gao, Q.; Hashimoto,

S.; Mareckova, K.; Pipatti, R.; Zhang, T.

2007 Waste Management, in Climate Change 2007. Mitigation, Contribution of Working Group III to the Fourth Assessment Report of the Intergovernmental Panel on Climate Change. Cambridge University Press, Cambridge, United Kingdom and New York, NY, USA.

Braschkat, J.; Patyk, A.; Quirin, M.; Reinhardt, G.A.

2003 Life cycle assessment of bread production - a comparison of eight different scenarios. In: 4th International Conference on: Life Cycle assessment in the Agri-food. Halber, N. and Weidema, B. (Ed). Horsens, Denmark. Danish Institute of Agricultural Sciences.

Brentrup, F.; Küsters, J.; Lammel, J.; Kuhlmann, H. 2000 Methods to estimate on-field nitrogen emissions from crop production as an input to LCA studies in the agricultural sector. Int. J. LCA. 5: 349-357.

Brentrup, F.; Küsters, J.; Kuhlmann, H.; Lammel, J.

2004a Environmental impact assessment of agricultural production systems using the life cycle assessment methodology: I. Theoretical concept of a LCA method tailored to crop production. European Journal of Agronomy 20 (3): 247-264.

Brentrup, F.; Küsters, J.; Lammel, J.; Barraclough, P.; Kuhlmann, H. 2004b Environmental impact assessment of agricultural production systems using the life cycle assessment (LCA) methodology: II. The application to $\mathrm{N}$ fertilizer use in winter wheat production systems. European Journal of Agronomy 20 (3): 265-279.

Céspedes, M.C.

2005 Agricultura Orgánica. Principios y pautas de producción. Boletín INIA $N^{\circ} 131$. Ministerio de Agricultura. Instituto de Investigaciones Agropecuarias. Centro Regional de Investigación Quilamapu, Chillán, Chile. 131 p.

Charles, R.; Jolliet, G.; Pellet, D.

2006 Environmental analysis of intensity level in wheat crop production using life cycle assessment. Agric. Ecosyst. Environ. 113: 216-225.

De Gennaro, B.; Notarnicola, B.; Roselli, L.; Tassielli, G.

2011 Innovative olive-growing models: an environmental an economic assessment. Journal of Clearner Production, doi:10.1016/j.jclepro.2011.11.004.

EPA

2010 Environmental protection agency. Solid Waste Management and Greenhouse Gases. Documentation for Greenhouse Gas Emission and Energy Factors Used in the Waste Reduction Model (WARM). Management Practices and Background, documentation, composting. Consultado en diciembre de 2011. FAO

2007 El medio ambiente y la agricultura. Comité de Agricultura. Roma, 25-28 de abril de 2007. 16 p.

Gastó, J.; Rodrigo, P.; Aránguiz, I. (editores).

2002 Ordenación territorial: desarrollo de predios y comunas rurales: LOM Eds.; Facultad de Agronomía e Ingeniería Forestal, Pontificia Universidad Católica de Chile. Santiago, Chile. 995 p.

González, J.; Velasco, R.; Morales, G.

2000 Costos y rentabilidad de cultivos anuales VII y VIII regiones. Boletín $\mathrm{N}^{\circ} 41$. Chillán, Chile: Instituto de Investigaciones Agropecuarias (INIA)-Quilamapu.

Haas, G.; Wetterich, F.; Köpke, U.

2001 Comparing intensive, extensifield and organic grassland farming in southern Germany by process life cycle assessment. Agriculture, Ecosystems and Environment 83: 43-53.

Hischier, R.; Althaus, H.-J.; Bauer, Chr.; Doka, G.; Frischknecht R.; Jungbluth, N.; Margni, M.; Nemecek, T.; Simons, A.; Spielmann, $\mathrm{M}$.

2009 Documentation of changes implemented in ecoinvent Data v2.1. Final report ecoinvent data v2.1. Volume: 16. Swiss Centre for LCI. Dübendorf. CH.

Hokazono, S., Hayashi, K.

2012. Variability in environmental impacts during conversion from conventional to organic farming: a comparison among three rice production systems in Japan. Journal of Clearner Production, doi:10.1016/j.jclepro.2011.12.005

Hospido, A., Moreira, M.T., Feijoo, G.

2003 Life Cycle inventory of the Galician dairy sector. In: 4th International Conference on: Life Cycle assessment in 
the Agri-food. Halber, N. and Weidema, B. (Ed). Horsens, Denmark. Danish Institute of Agricultural Sciences. INIA

1985 Suelos volcánicos de Chile. Instituto de Investigaciones Agropecuarias. Ministerio de Agricultura. Chile.

IPCC 2006.

2006 IPCC Guidelines for National Greenhouse Gas Inventories, Prepared by the National Greenhouse Gas Inventories Programme, Eggleston, H.S.; Buendia, L.; Miwa, K.; Ngara, T. and Tanabe, K. (eds). Publicado por: IGES, Japón.

Iriarte, A.; Rieradevall, J.; Gabarrell, X.

2010 Life cycle assessment of sunflower and rapeseed as energy crops under Chilean conditions. Journal of Clearner Productions, 18: 336-345.

ISO 14040

2006 Gestión ambiental. Análisis de Ciclo de Vida. Principios y marcos. International Organization for Standardization, ISO. Norma Española. 30 p.

ISO 14044

2006 Gestión ambiental. Análisis de Ciclo de Vida. Requisitos y directrices. International Organization for Standardization, ISO. Norma Española. 56 p.

Lou, X.F.; Nair, J.

2009 The impact of landfilling and composting on greenhouse gas emissions - A review. Bioresource Technology. 100: 3792-3798.

Meisterling, K.; Samaras, C. y Schweizer, V.

2009 Decisions to reduce greenhouse gases from agriculture and product transport: LCA case study of organic and conventional wheat. Journal of Cleaner Production 17: 222-230.

Mellado, M.

2007 El trigo en Chile, colección libros INIA N ${ }^{\circ} 21$. Instituto de Investigaciones Agropecuarias, Centro Regional de Milà. L. Investigación (CRI) Quilamapu, Chillán, Chile. 684 p.

2003 Contributions to Life Cycle Analysis for Agricultural Systems. Site-dependency and soil degradation impact assessment. Tesis doctoral. Facultat de Ciències. Universitat Autònoma. Bellaterra.
Montalba, R.

2009 Cambio técnico agrario y sostenibilidad de los agroecosistemas. Guía curso "Agroecología y desarrollo rural sostenible". Unidad 1. Universidad de La Frontera. Temuco, Chile. $93 \mathrm{p}$.

Muñoz, E.

2008 Revaloración sustentable de residuos sólidos de la industria elaboradora de cloro soda mediante análisis de ciclo de vida. Tesis magíster. Universidad de La Frontera. Temuco, Chile. 80 p.

Nemecek, T.; Dubois, D.; Huguenin-Elie, O.; Gaillard, G.

2011 Life cycle assessment of Swiss farming systems. I. Integrated and organic farm. Agricultural Systems. 104: 217-232.

Peters, J.; García Quijano, J.; Conten, T.; Van Wyk, G.; Holden, N.M.; Ward, S.M.; Muys, B.

2003 A new land use impact assessment method for LCA: theorical fundaments and field validation. In: 4th International Conference on: Life Cycle assessment in the Agri-food. Halber, N. and Weidema, B. (Ed). Horsens, Denmark. Danish Institute of Agricultural Sciences.

Pizzigallo, A.; Granai, C.; Borsa, S.

2008 The join use of LCA and emergy evaluation for the analysis of two Italian wine farms. Journal of Environmental Management 86: 396-406.

Rouanet, J.; Romero, O.; Demanet, R.

1988 Áreas Agroecológicas en la IX Región. Descripción. Investigación y Proceso Agropecuario, Carillanca, INIA (Temuco, Chile) 7 (1): 18-23.

Roy, P.; Nei, D.; Orikasa, T.; Xu, Q.; Okadome, H.; Nakamura, N.; Shiina, T.

2009 A review of life cycle assessment (LCA) on some food products. Journal of Food Engineering 90: 1-10.

Schmitzberger, I.; Wrbka, Th.; Steurer, B.; Aschenbrenner, G.; Peterseil, J.; Zechmeister, H.G.

2005 How farming styles influence biodiversity maintenance in Austrian agricultural landscapes. Agriculture, Ecosystems and Environment. 108: 274-290.

Sharpley, A.; McDowell, R.; Kleinman, J.

2001 Phosphorus loss from land to water: integrating agricultural and environmental management. Plant and soil. 237: 287-307. 